The Illusion of Inclusion $\longrightarrow$ 
History, Culture, and Society Series

Sponsored by the Center for Mexican

American Studies

The University of Texas at Austin 


\section{The Illusion of Inclusion}

The Untold Political Story of San Antonio

by Rodolfo Rosales

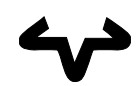

University of Texas Press, Austin 
Copyright $(\odot 2000$ by the University of Texas Press All rights reserved

Printed in the United States of America

First edition, 2000

Requests for permission to reproduce material from this work should be sent to Permissions, University of Texas

Press, P.O. Box 7819, Austin, TX 78713-7819.

(2) The paper used in this book meets the minimum requirements of ANSI/NISO Z39.48-1992 (R1997)

(Permanence of Paper).

Library of Congress Cataloging-in-Publication Data

Rosales, Rodolfo.

The illusion of inclusion : the untold political story of San Antonio / by Rodolfo Rosales. — 1st ed.

p. cm. - (History, culture, and society series)

Includes bibliographical references and index.

ISBN 0-292-77102-9 (cloth : alk. paper). — ISBN 0-292-77103-7 (pbk. : alk. paper)

1. Mexican Americans - Texas-San Antonio-Politics and government - 2oth century. 2. Middle class-Texas-San AntonioPolitical activity - History - 2oth century. 3. San Antonio (Tex.) Politics and government - 2oth century. 4. San Antonio (Tex.) -

Ethnic relations. 5. San Antonio (Tex.) - Social conditions-2oth century. I. Title. II. Series. F394.S29M57 2000

$324^{\prime} .089^{\prime} 68720764351-\mathrm{dc} 21 \quad 99-42794$ 
This is for

Those who dared to dream but are not with us anymore Those who still dream and dare to act on those dreams Those whom the dreams are for. 